\title{
A STUDY OF HEALTH SEEKING BEHAVIOR, HEALTH CARE SPENDING AND AWARENESS AMONG CASES OF MALARIA LIKE ILLNESS IN A TRIBAL AREA
}

Deodatt M Suryawanshi, Sati Prasad Sinha²

\section{HOW TO CITE THIS ARTICLE:}

Deodatt M Suryawanshi, Sati Prasad Sinha. "A Study of Health Seeking Behavior, Health Care Spending and Awareness among Cases of Malaria like Illness in a Tribal Area". Journal of Evolution of Medical and Dental Sciences 2014; Vol. 3, Issue 09, March 3; Page: 2302-2308, DOI: 10.14260/jemds/2014/2139

\begin{abstract}
Tribal malaria is a cause of high morbidity in India. Lack of affordable and accessible health care leads to out of pocket expenditure on malaria which is easily treatable under the NVBDCP. Lack of knowledge about causation and preventive measures about malaria predisposes to high incidence among Tribal. OBJECTIVES: 1 ) To study the prevalence of malaria like illness in the population 2) To study the health seeking behavior of the respondents 3) Study the health care spending on malaria like illness 4) Awareness among cases about malaria causation, prevention and control. MATERIAL AND METHODS: A descriptive cross sectional study was carried out during the month of September 2009 in three villages which fell under the Rural Health training center of a tertiary care medical .A Semi structured questionnaire was used to collect data from only those who had suffered from Malaria like illness with investigator visiting each household to enquire about malaria like illness in past 3 months. All the respondents who gave a positive history were included in the study. RESULTS: The study findings include (11\%) of people suffered Malaria like illness, $80 \%$ of patients took treatment other than sub center and PHC, mean cost of spending per visit was $62 \mathrm{rs,}$ $62 \%$ had no knowledge of malaria causation while 52\% used cow dung smoke to drive out the mosquitoes. CONCLUSION: Health seeking behavior of tribal people in malaria like illness is inclined more towards the Private physicians and faith healers. Out of pocket expenditure was high on diseases which can be treated free of cost under government sponsored programme. There was a general lack of knowledge about modes of transmission of malaria and methods of mosquito control. Inadequate active surveillance by the health worker was noted.
\end{abstract}

KEYWORDS: KAP Knowledge attitude and practices.

INTRODUCTION: Malaria is still endemic in over 100 countries worldwide. There were 216 million cases of malaria in 2010 globally ${ }^{1}$. In India, about 1.31 million malaria cases with 753 deaths were reported in the year 2011 out of which more than half cases were of Plasmodium falciparum. ${ }^{2}$

Tribal people live in one of the secluded areas of in India. Because of the remoteness of location, the extent to which they can benefit from general development programs is more limited. ${ }^{3}$ In such areas accessible to health care is poor. Tribal malaria is a common cause of morbidity and mortality among the Tribal People in India. Besides presence of environmental factors for cause of malaria, lack of education, poor knowledge and attitudes towards the disease are also the cause of high cases. ${ }^{4}$ Health seeking behavior is an important factor in success of public health delivery systems, but this is often overlooked while considering schemes for providing health facilities to people. As a result, new schemes for providing health care do not get the desired acceptance of the community, and are therefore rendered unsuccessful. ${ }^{5}$ About $47 \%$ of rural tribal live under poverty line. Most of them are employed in labor oriented jobs. Labour force participation FPR among STs is high as $69 \%$ due to poorer access to education .Their Monthly per capita expenditure is 617 Rs. of 
which $59 \%$ is spent on food intake. ${ }^{6}$ Out of Pocket Spending on a treatment of diseases like malaria which are treated free of cost under government programme puts economic burden on this communities pushing them under more poverty ${ }^{7}$ The present study was done with the intention to find out the health seeking behavior, expenditure on treatment and awareness among tribal population in a disease like malaria which is treated free of cost under Government health program of NVBDCP.

OBJECTIVES: The specific objectives of the study were to find out 1) The prevalence of malaria like illness in the population 2) Health seeking behavior during illness 3) Amount of out of pocket expenditure on an episode of illness 4) Awareness among cases about malaria causation, prevention and control.

MATERIALS AND METHODS: The study was a descriptive cross sectional study carried out during the month of September 2009. The study was conducted in three villages Sakwar, Goathan and Karelapada which are located approximately $90 \mathrm{kms}$ from Mumbai in Thane district, Maharashtra along the Mumbai Ahmedabad highway. These villages were selected for the study because they lie in the rural field practice area of a Tertiary care hospital and were easily accessible to the investigator. All the households were taken for the initial survey as the investigator needed to find out the incidence of malaria like illness in the community. Only those people who had episodes of high grade fever in past 3 months (June, July \& August) were included as study subjects while people complaining of fever associated with cough, cold, sore throat and Pyrexia of unknown origin or any fever associated with systemic symptoms were excluded. Out of the total Population (2135) covered by door to door survey, 58 respondents who gave history of even a single episode of high grade fever in past 3 months were taken as study subjects. A Semi structured questionnaire was used to collect data from only those who had suffered from Malaria like illness. Study respondents were asked about their Socio demographic characteristics, health seeking behavior in Malaria like illness and awareness of malaria causation and prevention. The data was analyzed using SPSS software version 16.

\section{RESULTS:}

SOCIO DEMOGRAPHIC CHARACTERISTICS OF STUDY RESPONDENTS: (Table no. 1) The total population covered by house to house survey of the three villages was 2135 , of which 58 cases of high grade fever were found with a incidence of $11 \%$. Of these 58 cases, $28(48 \%)$ were male $30(52 \%)$ female. Majority affected were in the 0 to 15 age group, the mean age was 24 . In the study majority of respondents $22(38 \%)$ were school going students followed by unskilled laborers $18(31 \%)$. Majority $30(52 \%)$ of the respondents were educated till primary level. The Mean income earned per month was Rs. 1344 with a SD of 514 Rs. Majority (53\%) complained of body ache and headache as major symptom during the episode of high grade fever. The mean duration of illness was 3 to 5 days in study subjects. Mean no of visits to health care facility were 2 times.

HEALTH SEEKING BEHAVIOUR: Following illness majority of the respondents $47(81 \%)$ visited health facility other than public health institutions. Majority $31(53 \%)$ visited private physicians, $10(17 \%)$ visited religious institutions while $6(10 \%)$ approached faith healer for treatment, while 
only 11(19\%) visited Public health institutions (Table no. 2). There was no significance found between Educational status of respondents and their health seeking behavior ( $p>0.05)$ (Table no 3 ). $11(18 \%)$ respondents were charged either free or somewhere between 1 to $10 \mathrm{rs} / \mathrm{visit}$. 42(71\%) of respondents spent from Rs. 10 to Rs. 100 on treatment per visit. The mean expenditure for one visit was 62 Rs. Public health Institutions like PHC, subcentre and pada worker treated the respondents free of cost, while private physicians charged them in the range of Rs. 10 to Rs. 150 (Table No. 4). Of the 58 fever cases, peripheral smear for malaria parasite was collected in only 11(19\%) of cases. Of the 11 people whose peripheral smear for malaria parasite was collected 2 turned out to be positive for malaria and were treated with chloroquine and primaquine by the subcentre staff.

AWARENESS: (Table no. 5) Majority of study respondents 45 (78\%) had heard of malaria while $13(22 \%)$ had never heard. Of the people who had heard about malaria 25(56\%) said they have heard it from local people, 13(29\%) from Televison, while and remaining 7(12\%) from the subcentre staff and pada worker. $36(62 \%)$ responded that they didn't know the cause of malaria. $14(24 \%)$ told that that getting wet in rain is the cause. $2(3 \%)$ told that it is due to change of climate and $1(2 \%)$ to Garbage collection around the house. Only 5(9\%) replied that malaria is caused by mosquito bite. Majority of the people $30(52 \%)$ used cow dung smoke to ward off the mosquitoes. Other 19(32\%) used Mosquito nets, $6(10 \%)$ used coils while 3(5\%) used both coils and nets. There was significant relationship between educational status and methods of protection used ( $p$ value $<0.01$ ) (Table no. 6). Most of them 35(60.3\%) did not know that malaria drugs are available free of cost for treatment. 54 (93\%) patients did not know that malaria can be prevented, while 34(57\%) responded that malaria is a life threatening disease. Majority of them emptied their water storage utensils once a week. All of the respondents covered the water use for domestic purposes. $20(34 \%)$ told that the malaria worker visits every 15 days in their house while $18(31 \%)$ told that he visits irregularly.

DISCUSSION: The Incidence of malaria like illness in the community was $11 \%$. All of the Study Respondents were from lower socio economic group, majority were students. 53\% of respondents complained of body ache and headache as accompanying symptom with fever .In study conducted by Verma Anupam et al $16 \%$ of respondents complained of headache and $10.4 \%$ of bodyache. ${ }^{8}$

In the Present study majority of respondents visited private sector, religious institution and local faith healer for treatment. In Similar study conducted by Das et al, faith healers remained the first point of contact outside the household and public health system for treatment. ${ }^{9}$

In the present study only $19 \%$ took treatment from Public Health institutions contrary to studies conducted by Verma A et $\mathrm{al}^{8}$ and Humphrey D. Mazigoi ${ }^{10}$ where majority percent of people sought treatment at government healthcare facilities.

There was no significant relationship found between educational status of respondents with their health seeking behavior, even primary and secondary educated people were going to faith healer. This was similar to study conducted by Das et al where education level of study respondents did not significantly influence the type of treatment respondents would select for malaria treatment. ${ }^{9}$

Majority of respondents in the study spent from Rs 10 to 100 for an episode of illness in private sector. Similarly in research conducted by Singh L Pet al people were willing to pay from Rs 10 to Rs 50 per patient if good qualified doctor visited their villages regularly. ${ }^{5}$ 
In the present study majority $36(62 \%)$ of respondents did not know the causative agent of malaria, Only $5(9 \%)$ people attributed the cause of malaria to mosquito bite. In Contrary to the present study, in studies conducted by V Soan ${ }^{4}$ and Singh $\mathrm{RK}^{11}, 37 \%$ and $28 \%$ of respondents respectively were aware that malaria is caused by mosquito.

In the present study there was no significance difference noted between educational level and knowledge of transmission ( $p>0.05)$. Similarly in study conducted by Singh $\mathrm{R} \mathrm{K}^{11}$ there was no significant difference in the knowledge about malaria transmission between literate and illiterate population of the village. In the present study 34(57\%) responded that malaria is a life threatening disease, contrary to study done by V Soan where $94.2 \%$ were not aware that malaria is a fatal disease. ${ }^{4}$

In the present study majority of people used cow dung smoke to avoid mosquito bite. In Study conducted by V Soan ${ }^{4}$ and Das et al $^{9}$ majority of people used smoke to avoid mosquito bite. There was significance relationship between educational status and methods of protection used ( $\mathrm{p}$ value $<0.01$ ) in the present study.

CONCLUSION: Health seeking behavior of tribal people in malaria like illness is inclined more towards the Private physicians and the other faith healer organizations. Out of pocket expenditure was high on a disease which the Government propagates to be treated free of cost with door to door surveillance.

There was a general lack of knowledge about modes of transmission of malaria and correct Mosquito control measures. There was inadequate surveillance by the multipurpose worker. Inadequate Malaria surveillance and lack of Health education on malaria control and prevention by the Health workers could be an important cause of people seeking treatment outside the public health institution.

\section{REFERENCES:}

1. World Malaria Report (2011). World health organisation. Global Malaria program.

2. National Vector Borne Disease Control Programme. Ministry of Health \&Family Welfare, Govt. of India, India.

3. Social inclusion. Social sectors .Twelfth five year plan (2012 to 2017); pg. no 228.

4. V Soan, Gyan Chand. Knowledge, Attitude and Practices towards Malaria in Tribal Community of Baigachak Area, Dindori District (MP). Proceedings of National Symposium on Tribal Health. Pg 75-78.

5. Singh L P, Gupta SD. Health Seeking Behaviour and Healthcare Services in Rajasthan, India: A Tribal Community's Perspective. Indian Institute of Health Management Research (IHMR working paper, no 1) .1997.

6. India Human Development Report 2011.Towards social Inclusion. pg no 98 -116.

7. Nkolika P Uguru et al. Inequities in incidence, morbidity and expenditures on prevention and treatment of malaria in southeast Nigeria. BMC Int Health Hum Rights. 2009; 9: 21.

8. Verma Anupam et al. KABP study of malaria in the rural areas of Utran, Surat. National Journal of Community Medicine 2010, Vol. 1(1)

9. Das et al. Community perceptions on malaria and care-seeking practices in endemic Indian settings: policy implications for the malaria control programme. Malaria Journal 2013; 12:39. 
10. Humphrey D. Mazigo et al. Knowledge, Attitudes, and Practices about Malaria and Its Control in Rural Northwest Tanzania. Malaria Research and Treatment, vol. 2010.

11. Singh RK, Haq S, Dhiman RC. Studies on Knowledge, Attitude and Practices in Malaria Endemic Tribal Areas of Bihar and Jharkhand, India. J Trop Dis (2013); 1: 110.

\begin{tabular}{|c|c|c|c|c|c|c|}
\hline & Male(n 28) & $\%$ & Female (n 30) & $\%$ & Total & $\%$ \\
\hline Age group & \multicolumn{6}{|c|}{ Gender distribution across age group } \\
\hline$<=15$ & 7 & $39 \%$ & 11 & $61 \%$ & 18 & $31 \%$ \\
\hline $16-30$ & 7 & $47 \%$ & 8 & $53 \%$ & 15 & $26 \%$ \\
\hline $31-45$ & 9 & $60 \%$ & 6 & $40 \%$ & 15 & $28 \%$ \\
\hline $46-60$ & 3 & $75 \%$ & 1 & $25 \%$ & 4 & $7 \%$ \\
\hline $61-75$ & 2 & $33 \%$ & 4 & $67 \%$ & 6 & $8 \%$ \\
\hline Total & 28 & $48 \%$ & 30 & $52 \%$ & 58 & \\
\hline \multicolumn{7}{|c|}{ Occupation } \\
\hline Unskilled & 15 & $53 \%$ & 3 & $6 \%$ & $18(31 \%)$ & $31 \%$ \\
\hline Skilled & 2 & $7 \%$ & 0 & 0 & $2(3 \%)$ & 26 \\
\hline Housewife & 0 & 0 & 15 & $50 \%$ & $15(26 \%$ & 28 \\
\hline Unemployed & 1 & $3 \%$ & 0 & 0 & $1(2 \%)$ & 7 \\
\hline Student & 10 & $36 \%$ & 12 & $40 \%$ & $22(38 \%)$ & 8 \\
\hline Total & 28 & & 30 & 51 & 58 & \\
\hline \multicolumn{7}{|c|}{ Educational status } \\
\hline Illiterate & 6 & $21 \%$ & 8 & $27 \%$ & 14 & 24 \\
\hline Primary & 14 & $50 \%$ & 16 & $53 \%$ & 30 & 52 \\
\hline Secondary & 8 & $29 \%$ & 6 & $20 \%$ & 14 & 24 \\
\hline Total & 28 & & 30 & $52 \%$ & 58 & \\
\hline \multicolumn{6}{|c|}{ Income of Head of family/month } & \\
\hline Rs & $\mathrm{n}$ & $\%$ & \multirow{7}{*}{\multicolumn{4}{|c|}{ Mean $=1344$ Rs, SD =514 }} \\
\hline$<=500$ & 1 & 2 & & & & \\
\hline $501-1000$ & 17 & 29 & & & & \\
\hline $1001-1500$ & 24 & 41 & & & & \\
\hline $1501-2000$ & 10 & 17 & & & & \\
\hline $2001-2500$ & 6 & 10 & & & & \\
\hline Total & 58 & 100 & & & & \\
\hline
\end{tabular}


ORIGINAL ARTICLE

\begin{tabular}{|l|c|c|c|c|c|c|c|}
\hline $\begin{array}{c}\text { Heath facility } \\
\text { visited }\end{array}$ & $\begin{array}{c}\text { Private } \\
\text { physician }\end{array}$ & $\begin{array}{c}\text { Religious } \\
\text { institution }\end{array}$ & $\begin{array}{c}\text { Faith } \\
\text { Healer }\end{array}$ & $\begin{array}{c}\text { Pada } \\
\text { worker }\end{array}$ & Subcentre & PHC & Total \\
\hline \multicolumn{1}{|c|}{$\mathrm{n}(\%)$} & $31(54 \%)$ & $10(17 \%)$ & $6(10 \%)$ & $4(7 \%)$ & $4(7 \%)$ & $3(5 \%)$ & 58 \\
\hline $\begin{array}{l}\text { Cost of } \\
\text { treatment/ } \\
\text { visit (Rs) }\end{array}$ & $\begin{array}{c}\text { Free \& } \\
(1 \text { to 10) }\end{array}$ & $\begin{array}{c}10 \text { to } \\
50 \mathrm{rs}\end{array}$ & $\begin{array}{c}51 \text { to } \\
100 \mathrm{rs}\end{array}$ & $\begin{array}{c}101 \text { to } \\
150 \mathrm{rs}\end{array}$ & $>150 \mathrm{rs}$ & & \\
\hline n(\%) , Mean \\
62.9 Rs, SD 74
\end{tabular}

\begin{tabular}{|l|c|c|c|c|c|c|c|}
\hline Education & $\begin{array}{c}\text { Pada } \\
\text { worker }\end{array}$ & $\begin{array}{c}\text { Sub } \\
\text { center }\end{array}$ & PHC & Religious & $\begin{array}{c}\text { Private } \\
\text { doctor }\end{array}$ & $\begin{array}{c}\text { Faith } \\
\text { Healer }\end{array}$ & Total (\%) \\
\hline Illiterate & 1 & 1 & 1 & 4 & 5 & 2 & $14(24 \%)$ \\
\hline Primary & 3 & 2 & 0 & 3 & 20 & 2 & $30(52 \%$ \\
\hline Secondary & 0 & 1 & 2 & 3 & 6 & 2 & $14(24 \%)$ \\
\hline Total & $\mathbf{4}(\mathbf{7 \% )}$ & $\mathbf{4 ( 7 \% )}$ & $\mathbf{3 ( 5 \% )}$ & $\mathbf{1 0 ( 1 7 \% )}$ & $\mathbf{3 1 ( 5 3 \% )}$ & $\mathbf{6 ( 1 0 \% )}$ & $\mathbf{5 8}$ \\
\hline
\end{tabular}

p value $>0.05$

\begin{tabular}{|c|c|c|c|c|c|c|}
\hline & $\begin{array}{c}\text { Free or } 1 \text { to } 10 \\
\text { Rs. }\end{array}$ & $\begin{array}{c}10 \text { to } 50 \\
\text { Rs. }\end{array}$ & $\begin{array}{c}51-100 \\
\text { Rs. }\end{array}$ & $\begin{array}{l}101-150 \\
\text { Rs. }\end{array}$ & $\begin{array}{l}>150 \\
\text { Rs. }\end{array}$ & $\begin{array}{c}\text { Total } \\
\%\end{array}$ \\
\hline Pada worker & 4 & 0 & 0 & 0 & 0 & $4(7 \%)$ \\
\hline Subcentre & 4 & 0 & 0 & 0 & 0 & $4(7 \%)$ \\
\hline $\mathrm{PHC}$ & 3 & 0 & 0 & 0 & 0 & $3(5 \%)$ \\
\hline $\begin{array}{l}\text { Religious } \\
\text { organization }\end{array}$ & 0 & 10 & 0 & 0 & 0 & $10(17 \%)$ \\
\hline Private Doctor & 0 & 9 & 17 & 4 & 1 & $31(53 \%)$ \\
\hline Faith Healer & 0 & 3 & 3 & 0 & 0 & $6(10 \%)$ \\
\hline Total & $11(19 \%)$ & $22(38 \%)$ & $20(34 \%)$ & $4(7 \%)$ & $1(1 \%)$ & 58 \\
\hline
\end{tabular}

\begin{tabular}{|l|l|l|l|}
\hline & & $\mathbf{n}$ & $\mathbf{\%}$ \\
\hline \multirow{3}{*}{$\begin{array}{c}\text { Heard of Malaria(Hivtap) } \\
\text { N =58) }\end{array}$} & Yes & 45 & 78 \\
\cline { 2 - 4 } & No & 13 & 22 \\
\cline { 2 - 4 } & Total & $\mathbf{5 8}$ & $\mathbf{1 0 0}$ \\
\hline \multirow{5}{*}{$\begin{array}{c}\text { Source Heard about Malaria } \\
(\mathrm{N}=45)\end{array}$} & Local people & 25 & 56 \\
\cline { 2 - 4 } & Television & 13 & 29 \\
\cline { 2 - 4 } & Subcentre staff & 6 & 10 \\
\cline { 2 - 4 } & Pada worker & 1 & 2 \\
\cline { 2 - 4 } & Total & $\mathbf{4 5}$ & $\mathbf{1 0 0}$ \\
\hline
\end{tabular}


ORIGINAL ARTICLE

\begin{tabular}{|l|l|l|l|}
\hline \multirow{4}{*}{ Causation of malaria (N =58) } & Don't Know & 36 & 62 \\
\cline { 2 - 4 } & Getting wet in rain & 14 & 24 \\
\cline { 2 - 4 } & Bite of Mosquito & 5 & 9 \\
\cline { 2 - 4 } & Change of climate & 2 & 3 \\
\cline { 2 - 4 } Methods used to prevent against & Collection of Garbage & 1 & 2 \\
\cline { 2 - 4 } mosquito bite (N =58) & Total & $\mathbf{5 8}$ & $\mathbf{1 0 0}$ \\
\hline \multirow{4}{*}{} & Cowdung gas & 30 & 52 \\
\cline { 2 - 4 } & Mosquito nets & 6 & 33 \\
\cline { 2 - 4 } & Mosquito coils & 3 & 10 \\
\cline { 2 - 4 } & Both nets and coils & $\mathbf{5 8}$ & 5 \\
\cline { 2 - 4 } & Total & $\mathbf{1 0 0}$ \\
\hline
\end{tabular}

\section{Table no. 5: Awareness about malaria causation and Preventive methods}

\begin{tabular}{|l|c|c|c|c|}
\hline $\begin{array}{c}\text { Preventive } \\
\text { methods }\end{array}$ & Illiterate & $\begin{array}{c}\text { Primary } \\
\text { level }\end{array}$ & $\begin{array}{c}\text { Secondary } \\
\text { level }\end{array}$ & Total \\
\hline Both nets and coils & 1 & 0 & 2 & $3(5 \%)$ \\
\hline mosquito nets & 4 & 13 & 2 & $19(33 \%)$ \\
\hline Mosquito Coils & 0 & 0 & 6 & $6(10 \%)$ \\
\hline Cowdung Gas & 9 & 17 & 4 & $30(52 \%)$ \\
\hline Total & $\mathbf{1 4}(\mathbf{2 4 \% )}$ & $\mathbf{3 0 ( 5 2 \% )}$ & $\mathbf{1 4 ( 2 4 \% )}$ & $\mathbf{5 8}$ \\
\hline
\end{tabular}

\section{Table no. 6: Education Status and Use of Preventive methods}

\section{P value $<0.05$}

\section{AUTHORS:}

1. Deodatt M Suryawanshi

2. Sati Prasad Sinha

\section{PARTICULARS OF CONTRIBUTORS:}

1. Assistant Professor, Department of Community Medicine, Dhanlakshmi Srinivasan Medical College, Perambalur, Tamilnadu.

2. Professor and HOD, Department of Community Medicine, Dhanlakshmi Srinivasan Medical College, Perambalur, Tamilnadu.

\section{NAME ADDRESS EMAIL ID OF THE} CORRESPONDING AUTHOR:

Dr. Deodatt M Suryawanshi, D 33, Medical Staff Quarters, Dhanlakshmi Medical College, Peramabalur - 621212,

Tamilnadu.

E-mail: drdeodattms1983@gmail.com

Date of Submission: 30/01/2014. Date of Peer Review: 31/01/2014. Date of Acceptance: 17/02/2014. Date of Publishing: 28/02/2014. 